\title{
Interaction Between Regional Innovation Market Stakeholders in the Context of Digital Transformation: Efficiency Assessment
}

\author{
Igor Polevoi \\ Department of Economic Innovation and Finance \\ Belgorod State National Research University \\ Belgorod, Russia \\ polevoy@bsu.edu.ru \\ Svetlana Pryadko \\ Department of Management and Marketing \\ Belgorod State National Research University \\ Belgorod, Russia \\ pryadko_s@bsu.edu.ru
}

\author{
Darya Korolkova \\ Department of Economic Innovation and Finance \\ Belgorod State National Research University \\ Belgorod, Russia \\ korolkova_d@bsu.edu.ru \\ Elena Danilova \\ Department of English Philology and Intercultural \\ Communication \\ Belgorod State National Research University \\ Belgorod, Russia \\ elena_danilova@bsu.edu.ru
}

\begin{abstract}
At the present stage, the formation of the market of innovative technologies is becoming a determining factor in the development of the economy of the Russian regions. Under, which should be understood as a set of economic relations that form the supply and demand of innovative technologies, their transfer, use and distribution, supported by appropriate institutions and mechanisms for the purpose of technological development of the economy. The purpose of the research is to find and develop new mechanisms for more effective interaction of the main stakeholders of the regional innovation market. This paper presents the results of the first stage of the study aimed at analyzing the efficiency of interaction between the main stakeholders in the regional innovation market, including innovation developers (regional universities) and subjects of innovative development (high-technology regional businesses). The study hypothesis was the assumption that the interaction between regional universities and business is effective, since an increase in the cost of intangible assets and implemented developments has a direct positive impact on the business performance in terms of revenues and profits. The main research methods were correlation and dispersion analysis of the indicators selected. As a result of the study, the hypothesis was partially confirmed, since only half of the enterprises showed a direct relationship.
\end{abstract}

Keywords-efficiency, stakeholder, regional innovation market, digital transformation.

\section{INTRODUCTION}

There is a long-felt need to improve the interaction between some stakeholders in the regional innovation market. It results from significant structural and institutional changes connected, inter alia, with the digital transformation of the region's economy. It explains the timely character of this research.

Apart from the use of digital technologies, the trend toward digital transformation contributes to building the platform for further development of the regional market which will significantly improve regional companies' efficiency [1]. The "Digital Economy of the Russian Federation" national program of 28 July, 2020, is now being implemented. According to it, digital technologies must be gradually introduced into all spheres of Russia's economy.

Major participants of these processes include innovation stakeholders, namely, the region's Universities (the subjects generating innovations) and representatives of the region's high technology business (the subjects implementing innovative developments created by university scholars). The subjects and objects of the regional innovation market are inter-connected by the process of innovative development transfer. In academic literature, the latter is often described as innovation commercialization, that is, its transfer to the market on a commercial basis.

In the course of fundamental digital transformation, the commercialization of a University's innovative developments has to provide for a complete innovation cycle, from search for promising $R \& D$ and supporting them to placing the sciencebased product in the market. However, data analysis shows that the process is sometimes uneven, with disproportionate volumes of financing and incentivation. This is why it is important, at this stage, to find ways to make the interaction between some regional innovation market stakeholders more effective. Apart from being a significant practical objective, it is also a timely research problem.

\section{METHODS}

The object of the study is the process of interaction between some stakeholders in the regional innovation market, namely, between the region's Universities and high-technology businesses. The study goal is to find opportunities enabling a more efficient interaction between the key stakeholders in the regional innovation market. 
Within this paper, the research problem is the contradiction resulting from the need to find ways of making the interaction between some innovation market stakeholders more efficient in terms of the region's digital transformation. The research hypothesis is the assumption that the efficient interaction between some stakeholders in the regional innovation market (universities and high-technology businesses) may be described as a positive correlation accompanied with an improved financial performance (higher revenues and net profits), as well as an increase in intangible assets and expenses on research and development.

We have conducted a study which comprises several stages. This paper presents a brief description of the first stage. We have used methods of regression, correlation and dispersion analysis in order to assess the efficiency of interaction between the selected stakeholders in the regional innovation market, namely, between universities and high-technology businesses.

Data available at the Audit-it.ru open access portal have been used as the research information basis. These include structured and partially visualized book-keeping data and tax information on the Russian companies' performance [2]

We have selected specific indices characterizing the efficiency of interaction between some stakeholders of the region's innovation market. These include ones characterizing the financial stability and solvency of top Belgorod companies, as well as the availability of intangible assets and R\&D results in the financial reports of the companies selected.

\section{MAIN PART}

We have analysed relevant theoretical data to find out that issues of building and developing regional innovation markets have raised increased scientific and practical interest in Russian academic papers over the last decades. These issues include, among other, the interaction between major stakeholders in the context of digital transformation. The region's universities have become full and active participants of the regional innovation market, since amendments to the legal framework allow them to put their developments on a commercial basis, that is, establish economic entities (small innovative businesses), release and sale technology-intensive products and so on.

Issues of interaction between innovation market stakeholders (universities and businesses) have been repeatedly addressed by European and North American authors. Google Scholar search engine suggests approximately two million academic sources for "interaction of innovation market participants" [3]. There is a persistent trend toward an increase in such statistics, as the number of papers and citations keeps rising, which bears witness to a high academic interest toward the topic.

According to Google Scholar, the "stakeholders of the innovation market" concept is mentioned over 889, 000 times in academic papers published in English [3]. It is not only thematic, but also geographic distribution of relevant papers and citations that arouses scientific interest. Thus, most cited and original papers include those by R.F. Hurley and G.T.M. Hult (1998) [4] with 5,533 citations; by J.K. Hall and M.J.C. Martin (2005) with 275 citations [5], by S. Ayuso, M.Á. Rodríguez and R.GarcíaCastro (2011) with 254 citations [6], by J.Goodman and A. Korsunova (2017) with 79 citations, [7], by R. Wongprawmas and R. Spadoni (2018) with 8 citations; by J.K. Juntunen, M. Halme and A. Korsunova (2019) with 21 citations, as well as works by a number of other scholars.

J. Hall and M. Martin suggest that suppliers, customers and complementary innovators represent major stakeholders of the innovation market. Based on K. Popper's theory of interested parties, innovations management concept and evolutional scientific method, the above scholars reveal the challenges posed by the implementation of drastic innovations in the market. Our study has shown that apart from facing technological, commercial and organizational uncertainties, the developers of such innovative technologies often have to deal with social issues. This is why it is important that the interested parties should be more proactive in creating the value-added chain of the innovative product [5].

The study by J. Goodman, A. Korsunova and M. Halme analyzes the possibility of companies' sustainable development. Their paper presents the results of 80 semi-structured interviews conducted in 13 European companies. A detailed qualitative analysis of the interested parties' activities in terms of innovation processes shows that the interested parties do not only exert pressure or manage expectations about controversial issues. They also play additional roles when innovations are implemented at enterprises, namely, the role of a stimulator, initiator, broker/mediator, concept refiner, legitimator, educator, context enabler and impact extender. Traditional roles of a legitimator and an educator prove to be less common in the study, while emerging roles such as stimulator, concept refiner, context enabler and impact extender are described by the authors as "clearly identifiable" and are more valuable for innovation implementation. Based on the above, J. Goodman, A. Korsunova and $\mathrm{M}$. Halme argue that secondary stakeholders may be more relevant than primary ones in the implementation of innovations [7].

Further research conducted by the group of scholars has shown that the key objective of a company's innovative development does not include only the implementation of innovations in products, services and business patterns. It also requires that long-term sustainable development should be attained. For this purpose, innovators may strive to improve their innovative potential using ideas, knowledge and the experience of their stakeholders. In doing so, they need to take into consideration what stakeholders should be integrated in new products development (NPD), to what extent and at which stage they should be involved. For this purpose, the authors have singled out three innovation strategies of enterprise development, based on their previous study ( $80 \mathrm{semi}$-structured interviews conducted in 13 European companies). These strategies include:

progressive transparency which means a deep organizational interaction with the interested parties, which enables the latter to exert a fundamental influence on innovations in terms of sustainable development (in case of an early secondary strategy indicating a progressive transparency, companies integrate secondary interested parties at an early stage, thus maximizing the impact of various opinions on innovations);

- the fine-tuning strategy which suggests that the share of secondary stakeholders should be restricted, and external entries should only be allowed after an indefinite phase of preliminary processing, when the key innovation-related decisions have already been taken;

- limited transparency for the integration of interested parties, which means that the number of stakeholder groups is limited, with no restrictions for their participation period.

Thus, we have made a brief review of relevant academic papers to reveal the following:

- first, depending on the study purposes, the main stakeholders of the innovation market may include businesses (those creating innovative products, services, business patterns et cetera), as well as customers, intermediaries in promoting 
innovative products to the markets and so on. The designers of innovations are often beyond the scope of study, which makes it difficult to assess the efficiency of their influence on the innovation market performance;

- second, most authors describe the process of an innovative development being transferred to the market as the most challenging stage of the innovation cycle. In other words, an assessment of the interaction between the innovation developers at the research stage may influence the efficiency of further cooperation between major market participants [5, 6, 10,11,12];

- third, there are challenges of assessing how efficiently an innovation has been implemented in a company's activity and whether it can provide not only a short-term positive effect but contribute to a business's sustainable development $[7,8,9]$.

We have studied a number of issue-related sources. According to statistics, major stakeholders of innovation markets are usually represented by innovatively active companies; intermediaries promoting innovations to the market; research centres and so on [2]. Still, most scholars believe the process of transferring innovative developments to the market to be the most challenging stage of the innovation cycle $[3,4,6,8]$.
An important applied objective of the innovative development is a search for more efficient ways of interaction between the innovation market stakeholders.

In order to simulate a pattern of interaction between the main stakeholders of the regional innovation market, we have conducted a study including several stages. Our working hypothesis at the first stage was an assumption that the implementation of universities' innovative developments exerts a direct positive influence on the efficiency of regional companies. To verify this hypothesis, we have used financial performance data of five top companies operating in Belgorod region.

For the search purposes at this stage, we have selected companies depending on their location, excluding other parameters, such as type of activity, specifics, scale of operations and so on. We have chosen "revenue" and "net profit" as performance indices. We compared them with intangible assets (patents, license agreements, trademarks, utility patterns, software, databases et cetera) and cost index which indicates the use of R\&D in the company (See Table 1).

\begin{tabular}{|c|c|c|c|c|c|c|c|}
\hline Company & 2012 & 2013 & 2014 & 2015 & 2016 & 2017 & 2018 \\
\hline \multicolumn{8}{|c|}{ Lebedinsky GOK JSC (Lebedinsky Mining and Processing Plant JSC) } \\
\hline Revenue & $\begin{array}{l}67,731 \\
850\end{array}$ & $\begin{array}{l}68,826 \\
706\end{array}$ & $65,434,797$ & $66,835,441$ & $74,055,862$ & $\begin{array}{l}104,534 \\
415\end{array}$ & $135,206,984$ \\
\hline Net profit (loss) & $\begin{array}{c}25,567 \\
955 \\
\end{array}$ & $\begin{array}{c}19,813 \\
266\end{array}$ & $75,085,434$ & $(6,238810)$ & $100,959,640$ & $50,521,875$ & $59,690,685$ \\
\hline Intangible assets & 1,406 & 1,266 & 1,164 & 1,073 & 864 & 818 & 705 \\
\hline $\begin{array}{c}\text { Research and } \\
\text { Development results }\end{array}$ & 885 & 705 & 525 & 345 & 165 & 0 & 0 \\
\hline \multicolumn{8}{|c|}{ JSC “OEMK” (Oskol Electrometallurgical Plant JSC) } \\
\hline Revenue & $\begin{array}{c}64,435 \\
181\end{array}$ & $\begin{array}{l}57,891 \\
806\end{array}$ & $67,499,632$ & $76,030,779$ & $79,549,823$ & $93,864,852$ & $117,758,967$ \\
\hline Net profit (loss) & $\begin{array}{c}4,675 \\
127\end{array}$ & $1,996,567$ & $11,620,879$ & $(937,664)$ & $30,388,842$ & $13,173,180$ & $14,483,388$ \\
\hline Intangible assets & 1,250 & 1,170 & 1,085 & 1,005 & 926 & 847 & 769 \\
\hline $\begin{array}{c}\text { Research and } \\
\text { Development results }\end{array}$ & 9,225 & 13613 & 18,628 & 19,656 & 24,935 & 26,786 & 41,669 \\
\hline Revenue & $\begin{array}{c}39,295 \\
610 \\
\end{array}$ & $\begin{array}{c}32,868 \\
815\end{array}$ & $38,985,601$ & $54,985,416$ & $75,564,771$ & $84,867,572$ & $98,852,319$ \\
\hline Net profit (loss) & 93,724 & 91,282 & 301,763 & 439,751 & 1,331 & 65,525 & 146,696 \\
\hline Intangible assets & 5,303 & 4,357 & 3,387 & 5,531 & 24,961 & 39,714 & 27,335 \\
\hline $\begin{array}{c}\text { Research and } \\
\text { Development results }\end{array}$ & 0 & 0 & 0 & 0 & 0 & 0 & 0 \\
\hline \multicolumn{8}{|c|}{ Stoilensky GOK JSC (Stoilensky Mining and Beneficiation Plant JSC) } \\
\hline Revenue & $\begin{array}{l}39,751 \\
899\end{array}$ & $\begin{array}{l}41,069 \\
389\end{array}$ & $38,066,033$ & $33,755,170$ & $37,498,910$ & $52,774,377$ & $72,816,201$ \\
\hline Net profit (loss) & $\begin{array}{c}19,629 \\
329\end{array}$ & $\begin{array}{l}24,656 \\
899\end{array}$ & $30,606,024$ & $16,620,557$ & $12,882,637$ & $23,515,429$ & $43,833,288$ \\
\hline Intangible assets & 628 & 2,674 & 5,481 & 7,633 & 21,430 & 16,048 & 34,724 \\
\hline $\begin{array}{c}\text { Research and } \\
\text { Development results }\end{array}$ & 0 & 0 & 22,717 & 22,426 & 22,426 & 10,304 & 3,031 \\
\hline \multicolumn{8}{|c|}{ SK Korocha JSC } \\
\hline Revenue & $\begin{array}{l}23,092 \\
689\end{array}$ & $\begin{array}{l}27,835 \\
403\end{array}$ & $41,520,968$ & $46,088,189$ & $45,205,568$ & $47,102,314$ & $51,995,711$ \\
\hline Intangible assets & 183 & 105 & 28 & 0 & 0 & 0 & 758 \\
\hline $\begin{array}{c}\text { Research and } \\
\text { Development results }\end{array}$ & 0 & 0 & 0 & 0 & 0 & 0 & 0 \\
\hline
\end{tabular}

The above data show that intangible assets appear on the balance sheets of all the top companies of Belgorod region. At the same time, they make up for less than $1 \%$ at each of the companies under study, which is in line with the general Russian trend. According to Skolkovo Community, intangible assets make up for a significant part of the cost at research and production associations only, and such associations are quite few [20].

But, unlike intangible assets that are on the balance sheet of all surveyed enterprises, data on the results of research and development are presented in the financial statements of only three enterprises: Lebedinsky Mining and Processing Plant 
JSC, Oskol Electrometallurgical Plant JSC and and Stoilensky Mining and Beneficiation Plant JSC. Moreover, only in Oskol Electrometallurgical Plant JSC this indicator has a stable growth trend. The dynamics of this indicator for the analyzed period was $451 \%$. At and Stoilensky Mining and Beneficiation Plant JSC, data on the results of research and development appeared on the balance sheet of the enterprise only in 2014. This was the maximum level of this indicator $(22,717$ thousand rubles). Subsequently, the indicator began to decline, and in 2018 it amounted to 3,031 thousand rubles. The indicator "results of research and development" in Lebedinsky Mining and Processing Plant JSC showed a negative trend. During the analyzed period of time there was a decrease in the indicator from 885 thousand rubles. to zero in 2017 and 2018.

Thus, the analysis of the primary information collected for the study showed that even in the financially stable leading enterprises of the Belgorod region, the results of research and development occupy an insignificant amount of enterprise assets. To analyze the relationship between the selected indicators, we carried out a statistical analysis.

In order to verify the working hypothesis of the first stage of our study, we have analyzed the correlation between the above indices. Table 2 presents generalized analysis results.

TABLE 2. CLIENT-SERVER EXPERIMENTAL RESULTS

\begin{tabular}{|c|c|c|c|c|c|c|c|c|c|}
\hline Company & & Ratios & $\begin{array}{l}\text { Standard } \\
\text { error }\end{array}$ & t-statistic & P-value & $\begin{array}{l}\text { Lower } \\
95 \%\end{array}$ & $\begin{array}{l}\text { Upper } \\
95 \%\end{array}$ & $\begin{array}{l}\text { Lower } \\
95.0 \%\end{array}$ & $\begin{array}{l}\text { Upper } \\
95.0 \%\end{array}$ \\
\hline \multirow{3}{*}{$\begin{array}{lcr}\text { Lebedinsky } & \text { GOK } & \text { JSC } \\
\text { (Lebedinsky } & \text { Mining } & \text { and } \\
\text { Processing Plant JSC) } & \end{array}$} & $\begin{array}{c}\mathrm{Y}- \\
\text { intersection }\end{array}$ & 99137940.45 & 27169563 & 3.64886 & 0.014766 & 29296356 & $1.69 \mathrm{E}+08$ & 29296356 & $1.69 \mathrm{E}+08$ \\
\hline & $\begin{array}{c}\mathrm{X} 1 \\
\text { variable }\end{array}$ & $\begin{array}{c}- \\
19908.40822 \\
\end{array}$ & 23008.95 & -0.86525 & 0.42646 & -79054.8 & 39237.99 & -79054.8 & 39237.99 \\
\hline & Conclusion & \multicolumn{8}{|c|}{$\begin{array}{c}\mathrm{Y}=99137940.45-19908.40822 \mathrm{x} \\
\text { Weak and inverse correlation of indices. }\end{array}$} \\
\hline \multirow{3}{*}{$\begin{array}{lcr}\text { JSC } & \text { "OEMK" } & \text { (Oskol } \\
\text { Electrometallurgical } & \text { Plant } \\
\text { JSC) } & & \end{array}$} & $\begin{array}{c}\mathrm{Y}- \\
\text { intersection }\end{array}$ & $1.54 \mathrm{E}+08$ & 15795824 & 9.758289 & 0.000192 & $1.14 \mathrm{E}+08$ & $1.95 \mathrm{E}+08$ & $1.14 \mathrm{E}+08$ & $1.95 \mathrm{E}+08$ \\
\hline & $\begin{array}{c}\mathrm{X} 1 \\
\text { variable }\end{array}$ & -76999.2 & 14851.03 & -5.18477 & 0.003511 & -115175 & -38823.5 & -115175 & -38823.5 \\
\hline & Conclusion & \multicolumn{8}{|c|}{$\begin{array}{l}\mathrm{Y}=154140225.2-76999.2 \mathrm{x} \\
\text { Strong and inverse correlation. } \\
\text { angible assets, the lower the company's revenue and profit }\end{array}$} \\
\hline \multirow{3}{*}{$\begin{array}{l}\text { KRC EFKO Cascade LLC } \\
\text { (EFKO-Cascade } \\
\text { Coordination } \\
\text { Distribution Centre LLC) }\end{array}$} & $\begin{array}{c}\mathrm{Y}- \\
\text { intersection }\end{array}$ & 37454586 & 3984474 & 9.400133 & 0.00023 & 27212169 & 47697003 & 27212169 & 47697003 \\
\hline & $\begin{array}{c}\mathrm{X} 1 \\
\text { variable }\end{array}$ & 1278.121 & 220.3216 & 5.801161 & 0.002146 & 711.7664 & 1844.476 & 711.7664 & 1844.476 \\
\hline & Conclusion & \multicolumn{8}{|c|}{$\begin{array}{l}\mathrm{Y}=37454586+1278.121 \mathrm{X} \\
\text { Strong and direct correlation. } \\
\text { ingible assets, the higher the company's revenue and profit }\end{array}$} \\
\hline \multirow{3}{*}{$\begin{array}{lcr}\text { Stoilensky } & \text { GOK } & \text { JSC } \\
\text { (Stoilensky } & \text { Mining } & \text { and } \\
\text { Beneficiation } & \text { Plant JSC) }\end{array}$} & $\begin{array}{c}\mathrm{Y}- \\
\text { intersection }\end{array}$ & 39066792 & 3479178 & 11.22874 & $9.78 \mathrm{E}-05$ & 30123281 & 48010302 & 30123281 & 48010302 \\
\hline & $\begin{array}{c}\mathrm{X} 1 \\
\text { variable }\end{array}$ & 181.4131 & 322.7018 & 0.562169 & 0.598268 & -648.118 & 1010.944 & -648.118 & 1010.944 \\
\hline & Conclusion & \multicolumn{8}{|c|}{$\begin{array}{c}\mathrm{Y}=39066792+181.4131 \mathrm{X} \\
\text { Weak and direct correlation of indices. } \\
\text { The higher the value of intangible assets and R\&D implemented, the higher the company's revenue and } \\
\text { profit }\end{array}$} \\
\hline \multirow[t]{3}{*}{ SK Korocha JSC } & $\begin{array}{c}\mathrm{Y}- \\
\text { intersection } \\
\end{array}$ & 46254745 & 1553349 & 29.77744 & 8.01E-07 & 42261735 & 50247755 & 42261735 & 50247755 \\
\hline & $\begin{array}{c}\mathrm{X} 1 \\
\text { variable }\end{array}$ & -158047 & 12175.2 & -12.981 & 4,84E-05 & -189344 & -126749 & -189344 & -126749 \\
\hline & Conclusion & \multicolumn{8}{|c|}{$\begin{array}{c}\mathrm{Y}=46254745-158047 \mathrm{x} \\
\text { Weak and inverse correlation of indices. }\end{array}$} \\
\hline
\end{tabular}

The above data reveal a direct positive correlation of indices in half of the cases only. EFKO-Cascade Coordination and Distribution Centre LLC is the only company displaying a strong and direct correlation of indices. It means that the implementation of research and development results and the availability of intangible assets have exerted a direct positive influence on the company's performance, resulting in increased revenue and net profit. Stoilensky Mining and Beneficiation Plant JSC also displays a direct correlation of indices, though it is rather weak. In the other cases, the availability of intangible assets on the companies' balance sheets has not influenced the revenues and net profit directly.

In other cases, the presence of intangible assets on the balance sheet of an enterprise did not have a direct impact on the increase in revenue and net profit of enterprises. Moreover, Oskol Electrometallurgical Plant JSC, on the balance sheet of which intangible assets were declining, and the results of research and development had a positive trend, demonstrated an inverse and strong relationship of indicators. That is, the more the value of intangible assets increased, the lower the revenue and profit of the enterprise became.

Drawing 1 presents a visualization of our findings. The data visualization above shows that the range of indices under study is insignificant for all the region's companies which implement R\&D and possess intangible assets. However, only two companies of the first group display positive correlation trends, namely, EFKO-Cascade Coordination and Distribution Centre LLC and Stoilensky Mining and Beneficiation Plant JSC. 

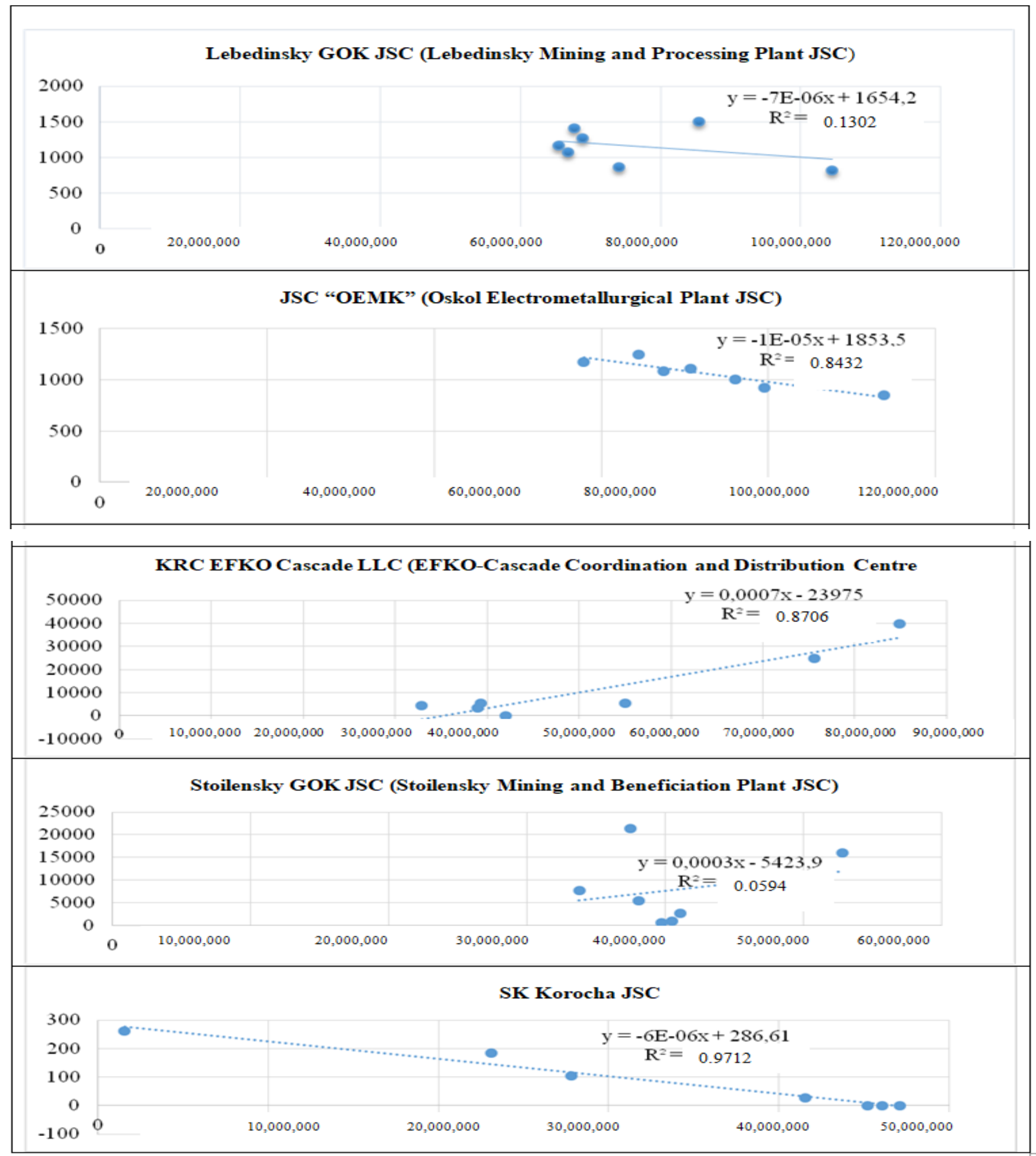

Fig. 1. Correlation trends of companies' financial performance indices

\section{CONCLUSION}

Thus, the study showed that the main stakeholders of the innovative regional market are not only innovation-oriented high-tech businesses, consumers and intermediaries working in this market. The main stakeholders should also include R\&D developers: regional universities, research laboratories, centers, etc. To build a model of interaction between the selected stakeholders and assess the effectiveness of the implementation of innovative developments, we carried out a statistical analysis of the financial indicators of five leading enterprises in the
Belgorod region. At this stage of the research, we have used data from Audit-it.ru information portal to select enterprises based on their geographical location and combine them into groups depending on the revenue volumes. The study has enabled us to verify the working hypothesis partially, as only in half of the cases performance indicators display a direct correlation and a positive trend. This partial verification of the working hypothesis will lay the foundation for the next stage of the research which will include a cluster analysis of the enterprises and assessment of how efficient the implemented innovations are in the addedvalue chain of the region's high-technology products. 


\section{REFERENCES}

[1] The Digital Economy of the Russian Federation, national program Approved by the order of Russian Federation Government of 28 July, 2017, No. 1632-r.

[2] Revenue ranking of companies. Audit-it.ru Book-keeping. Taxes. Audit. URL: https://www.testfirm.ru/rating/belgorodskaya-oblast/ (accessed 10.11.2020)

[3] Google Scholar. Google Academy [Electronic resource]. URL: https://scholar.google.com (accessed 10.11.2020).

[4] R.F. Hurley, G.T. Hult, "Innovation, market orientation, and organizational learning: an integration and empirical examination", Journal of marketing, $1998 . \quad$ URL: https://journals.sagepub.com/doi/10.1177/002224299806200303 (accessed 10.11.2020).

[5] J.K. Hall, M.J.C. Martin, "Disruptive technologies, stakeholders and the innovation value-added chain: a framework for evaluating radical technology development”, R\&D Management, 2005. URL: https://onlinelibrary.wiley.com/doi/abs/10.1111/j.14679310.2005.00389.x (accessed 10.11.2020).

[6] S. Ayuso, M.Á. Rodríguez, R. García-Castro, "Does stakeholder engagement promote sustainable innovation orientation?", Industrial Management \& Data Systems, 2011. URL: Retrieved from https://www.emerald.com/insight/content/doi/10.1108/026355711111 82764/full/html (accessed 10.11.2020)

[7] J. Goodman, A. Korsunova, M. Halme Our collaborative future: Activities and roles of stakeholders in sustainability-oriented innovation. Business Strategy and the Environment, 2017. 26. 731-753. 10.1002/bse.1941.

[8] R. Wongprawmas, R. Spadoni, "Is innovation needed in the Old World wine market? The perception of Italian stakeholders", British Food Journal, $2018 . \quad$ URL: https://www.emerald.com/insight/content/doi/10.1108/BFJ-07-20170409/full/html?skipTracking=true emerald.com (accessed 10.11.2020).

[9] J. Juntunen, K. Jouni, M. Halme, A. Korsunova, R. Rajala, "Strategies for Integrating Stakeholders into Sustainability Innovation. A Configurational Perspective", Journal of Product Innovation Management, 2019.,36, pp. 331-355. 10.1111/jpim.12481.

[10] N. Franke, F. Piller, "Value Creation by Toolkits for User Innovation and Design: The Case of the Watch Market", Journal of Product Innovation management, 2004;21, pp.401-415.

[11] G.D. Markman, P.T. Gianiodis, P.H. Phan, D.B. Balkin, "Innovation speed: Transferring university technology to market", Research policy, 2005.

[12] F. Zhao, "Initiatives to promote commercialization of university knowledge. Commercialization of research: a case study of Australian universities", Higher Education Research \& Development, 2004.

[13] P. Hemert, P. Nijkamp, E. Masurel, From innovation to commercialization through networks and agglomerations: Analysis of sources of innovation, innovation capabilities and performance of Dutch SMEs, The Annals of Regional Science, 2013, 50. 10.1007/s00168-012-0509-1.

[14] G.D. Markman, D.S. Siege, "Research and technology commercialization", Journal of Management, 2008. URL: https://onlinelibrary.wiley.com/doi/full/10.1111/j.1467-

6486.2008.00803.x (accessed 10.11.2020).

[15] E. Rasmussen, "Government instruments to support the commercialization of university research: Lessons from Canada.", Technovation, 2008, 28, pp.506-517. 10.1016/j.technovation.2007.12.002.

[16] A. Kumaraswamy, R. Garud, "Perspectives on disruptive innovations", Journal of Management Studies, $2018 . \quad$ URL: https://onlinelibrary.wiley.com/doi/abs/10.1111/joms.12399 (accessed 10.11.2020).

[17] D. Bok, Universities in the marketplace: The commercialization of higher education, 2009. URL:books.google.com (accessed 10.11.2020).

[18] D.S. Siegel, D.A. Waldman, L.E. Atwater, A.N. Link "Toward a Model of the Effective Transfer of Scientific Knowledge from Academicians to Practitioners: Qualitative Evidence from the
Commercialization of University Technologies", Journal of Engineering and Technology Management, 2004, 21, pp.115-142. 10.1016/j.jengtecman.2003.12.006.

[19] M. Sharma, U. Kumar, L. Lalande, "Role of university technology transfer offices in university technology commercialization: case study of the CarletonUniversity foundry program", Journal of Services Research, 2006. URL: Retrieved from: http://citeseerx.ist.psu.edu/viewdoc/download?doi=10.1.1.466.4306\& rep=rep1\&type=pdf $($ accessed 10.11.2020).

[20] Skolkovo Community, Skolkovo. URL: http://sk.ru/net/p/media 